\title{
Catch and release with DNA by imidazolium-presenting iron oxide nanoparticles via anion exchange
}

$\operatorname{AUTHOR}(\mathrm{S})$ :

Tanaka, Kazuo; Narita, Asako; Chujo, Yoshiki

\section{CITATION:}

Tanaka, Kazuo ... [et al]. Catch and release with DNA by imidazolium-presenting iron oxide nanoparticles via anion exchange. Composite Interfaces 2013, 20(1): 27-32

ISSUE DATE:

2013-02

URL:

http://hdl.handle.net/2433/187104

\section{RIGHT:}

(c) 2013 Taylor \& Francis; This is an Accepted Manuscript of an article published by Taylor \& Francis Group in 'Composite Interfaces' on 2013-02, available online at: http://www.tandfonline.com/10.1080/15685543.2013.762891.; This is not the published version. Please cite only the published version.; この論文は出版社版でありません。引用の際には出版社版 をご確認ご利用ください。 


\title{
Catch and Release with DNA by Imidazolium- Presenting Iron Oxide Nanoparticles via Anion
}

\section{Exchange}

\author{
Kazuo Tanaka, Asako Narita, Yoshiki Chujo* \\ Department of Polymer Chemistry, Graduate School of Engineering, Kyoto University, \\ Katsura, Nishikyo-ku, Kyoto 615-8510, Japan
}

\section{CORRESPONDING AUTHOR FOOTNOTE}

E-mail: chujo@chujo.synchem.kyoto-u.ac.jp.

Phone: +81-75-383-2604.

Fax: +81-75-383-2605.

\section{KEY WORDS}

ion exchange, iron oxide, nanoparticle, imidazolium 


\begin{abstract}
We present the catch and release technique with DNA using imidazolium-presenting nanoparticles via anion exchange. The imidazolium-tethered superparamagnetic iron oxide (SPIO) was prepared, and the binding behavior to DNA was investigated. Accordingly, when the imidazolium cation forms an ion pair with the hydrophilic anion such as chloride, DNA can be absorbed onto the modified SPIO. In contrast, by anion exchange to hydrophobic anion such as $\mathrm{TFSA}^{-}$, the binding affinity greatly decreased, resulting in the release of DNA. Moreover, the release efficiency can be improved by introducing a silica layer at the surface of SPIOs. Finally, the catch and release with DNA was accomplished under mild conditions.
\end{abstract}




\section{Introduction}

Isolation of nucleic acids is a fundamental and essential technique in biotechnology. ${ }^{1}$ The target sequence must be extracted from biological samples without mutation or scission during operations in the sequencing and the preparing of DNA library. Therefore, the extraction method in which catch and release with nucleic acids should proceed under mild conditions has been still desired. Superparamagnetic iron oxide (SPIO) has been widely used for the bio-related materials involving for nucleic acids collection. ${ }^{2-4}$ Based on attractive forces with a magnet, the target molecules and sequences can be readily collected. The development of the release procedure under mild condition is beneficial to collect the target molecules without damage or denaturation.

Ionic liquids (ILs), which are defined as a pure salt with the melting temperature below $100{ }^{\circ} \mathrm{C}$, have attracted attention as a surface modification for metal nanoparticles. ${ }^{5,6}$ Imidazolium cations which are one of typical components of ILs are a versatile and feasible molecule to provide the functions of ILs to metal nanoparticles. ${ }^{5,6}$ Previously, it was shown that the imidazolium-presenting SPIOs can work as a contrast agent in magnetic resonance imaging with good biocompatibility. ${ }^{7}$ In addition, DNA can be adsorbed onto the surface of the imidazolium-presenting iron oxide nanoparticles via electrostatic interaction..$^{7}$ We have recently reported the regulation of the assembly states of the modified gold nanoparticles. $^{8}$ Especially, by modulating the hydrophobicity of the anions, not only the dispersion/aggregation states but also the inter-particle distances in the assembly were modulated. ${ }^{8}$ Next our interest has directed to apply the anion exchange of counter ions in IL molecules for developing practical biotechnology such as DNA purification.

Herein, we report the establishment of the catch and release system with DNA based on the imidazolium-presenting SPIOs. By changing the hydrophobicity of the surface modification, DNA can be efficiently catched and released with the modified nanoparticles. We also mention the improvement 
of the releasing ability by using the silica-coated core/shell-type SPIOs. Finally, we accomplished to demonstrate the extraction of DNA under mild conditions. 


\section{Experimental Section}

Preparation of the modified SPIOs. Iron(III) chloride hexahydrate (1.081 g, $4 \mathrm{mmol})$ and iron(II) chloride tetrahydrate $(0.3976 \mathrm{~g}, 2 \mathrm{mmol})$ were dissolved in water $(140 \mathrm{~mL})$. After the addition of $5 \mathrm{~mL}$ of the acetone solution containing oleic acid $(0.2 \mathrm{~mL}, 0.63 \mathrm{mmol})$ with mechanically stirring at 1000 rpm, $15 \mathrm{~mL}$ of aqueous ammonium hydroxide $(28 \%)$ was added to the solution all at once. After stirring for $30 \mathrm{~min}$, the resulting dark brown suspension was cooled to room temperature. The naked nanoparticles were washed with water $(200 \mathrm{~mL})$ and with ethanol $(200 \mathrm{~mL})$ twice using a magnet. Then, the resultant iron oxide nanoparticles were well redispersed in ethanol/water $(140 \mathrm{~mL} / 1 \mathrm{~mL})$ by sonication for $20 \mathrm{~min}$. To the dispersion, 1-(trimethoxysilylpropyl)-3-methylimidazolium chloride $^{7}$ $(1.291 \mathrm{~g}, 4 \mathrm{mmol})$ in ethanol $(10 \mathrm{~mL})$ was added. The reaction mixture was vigorously stirred by a mechanical stirrer under nitrogen and heated at $70{ }^{\circ} \mathrm{C}$ for $6 \mathrm{~h}$. After cooling to room temperature, the resulting black solution was added to acetonitrile $(200 \mathrm{~mL})$ and the imidazolium-presenting iron oxide nanoparticles were collected with a magnet and washed with acetonitrile $(200 \mathrm{~mL})$ three times using a magnet. Finally, the modified iron oxide nanoparticles dispersed in a small amount of acetonitrile were added to tetrahydrofuran for precipitating, and then filtration and drying in vacuo gave the imidazolium presenting iron oxide nanoparticles as a black solid.

Silica coating on the iron oxide nanoparticles. The preparation of the silica-coated core/shell-type SPIOs was according to our previous report. ${ }^{9,10}$ In a $50 \mathrm{~mL}$ glass vial, $2.3 \mathrm{~g}$ of Igepal CO-520 ${ }^{\circledR}$ was dissolved in $45 \mathrm{~mL}$ of cyclohexane. The solution was mechanically stirring at $700 \mathrm{rpm}$ with sonication for $2 \mathrm{~min}$. After dispersing the SPIO particles, $0.3 \mathrm{~mL}$ of the mixture was added to the cyclohexane solution, and then the mixture was stirred at room temperature for $5 \mathrm{~min}$ with sonication. The resulting mixture was turned to transparent light brown liquid, and then $0.3 \mathrm{~mL}$ of tetraethoxysilane was added. The mixture was gently stirred by hand using spatula until tetraethoxysilane was completely dissolved, and the mixture was put for 3 days at room temperature to form thick silica shell. In $1000 \mathrm{~mL}$ of a round-bottom flask, the imidazolium $(2.0 \mathrm{~g})$ was dissolved in $200 \mathrm{~mL}$ of ethanol. The mixture 
containing the core/shell particles was rapidly added to the ethanol solution with mechanically stirring at $700 \mathrm{rpm}$. After the mixture was stirred for $12 \mathrm{~h}$ at room temperature, the upper transparent layer was removed, and the light-brown-colored products were separated by centrifuging at $6000 \mathrm{rpm}$. After washing with $200 \mathrm{~mL}$ of methanol three times, the desired core/shell particles were obtained as a brown suspension in methanol.

DNA adsorption experiments. The SPIOs were dispersed in $10 \mathrm{mM}$ Tris- $\mathrm{HCl}$ buffer $(\mathrm{pH}=8.0)$ containing $1 \mathrm{mM}$ EDTA with the concentration of $5 \mathrm{mg} / \mathrm{mL}$. The plasmid DNA (pBR322, 2.84106 Da was obtained from Nippon Gene Co., Ltd., Tokyo, Japan) was dissolved in $10 \mathrm{mM}$ Tris-HCl buffer containing $1 \mathrm{mM}$ EDTA $(\mathrm{pH}=8$,) with the concentration of $0.05 \mathrm{mg} / \mathrm{mL}$. The albumin solution was prepared as $50 \mathrm{mg} / \mathrm{mL}$ of bovine serum albumin (Wako Pure Chemical Industries, Ltd., Tokyo, Japan) in $10 \mathrm{mM}$ Tris- $\mathrm{HCl}$ buffer $(\mathrm{pH}=8.0)$ containing $1 \mathrm{mM}$ EDTA. To the solution mixture $(100 \mu \mathrm{L})$ with $25 \mu \mathrm{g} / \mathrm{mL}$ of DNA and in $10 \mathrm{mM}$ Tris $-\mathrm{HCl}$ buffer $(\mathrm{pH}=8.0)$ containing $1 \mathrm{mM}$ EDTA in the presence or absence of $25 \mathrm{mg} / \mathrm{mL}$ of albumin or $\times 1 / 2$ diluted fetal bovine serum (FBS), $5 \mu \mathrm{L}, 10 \mu \mathrm{L}$, and $15 \mu \mathrm{L}$ of the nanoparticle dispersion was added. After vortex for several seconds, the SPIOs were trapped by magnets (TOYOBO Magical trapper) and then the supernatant of each sample was transferred to a new tube and centrifuged for $10 \mathrm{~min}$ to further remove SPIOs completely. The supernatant $(10 \mathrm{~mL})$ of each sample was separated on a $0.8 \%$ agarose gel. The DNA in those gels was stained with the intercalating reagent ethidium bromide and visualized by UV light $(365 \mathrm{~nm})$ from Electronic UV transilluminator (TOYOBO FAS-III).

Exchanging the counter anions of the imidazolium cations on the surface of SPIOs. To the solution mixture $(100 \mu \mathrm{L})$ with $25 \mu \mathrm{g} / \mathrm{mL}$ of DNA and in $10 \mathrm{mM}$ Tris- $\mathrm{HCl}$ buffer $(\mathrm{pH}=8.0)$ containing $1 \mathrm{mM}$ EDTA and $\times 1 / 2$ diluted fetal bovine serum (FBS), $5 \mu \mathrm{L}, 10 \mu \mathrm{L}$, and $15 \mu \mathrm{L}$ of the SPIO dispersion was added. After washing with water, $0.5 \mathrm{M}$ potassium bis(trifluoromethanesulfonyl)amide (KTFSA) or $\mathrm{KCl}$ 
were added. The supernatant $(10 \mathrm{~mL})$ of each sample was separated on a $0.8 \%$ agarose gel. The DNA in those gels was stained with the intercalating reagent ethidium bromide and visualized by UV light (365 $\mathrm{nm}$ ) from Electronic UV transilluminator (TOYOBO FAS-III). The DNA was precipitated by adding $800 \mu \mathrm{L}$ of ethanol at $-40{ }^{\circ} \mathrm{C}$, and the precipitated DNA was washed with $100 \mu \mathrm{L}$ of $80 \%$ cold ethanol and dried in vacuo. The samples for gel electrophoresis were prepared by dissolving into $10 \mathrm{mM}$ Tris$\mathrm{HCl}$ buffer $(\mathrm{pH}=8.0)$ containing $1 \mathrm{mM}$ EDTA. 


\section{Results and Discussion}

The synthesis of the imidazolium-presenting SPIOs is outlined in Scheme $1 .{ }^{7,9,10}$ We initially prepared 1-(trimethoxysilylpropyl)-3-methylimidazolium chloride via the coupling reaction of 3chloropropyltrimethoxysilane with 1-methylimidazole. ${ }^{7}$ The imidazolium-directly-tethered SPIOs (ImSPIOs) were prepared by condensation with naked SPIOs. The silica-coated core/shell-type SPIOs (Imsilica-SPIOs) were also prepared. ${ }^{9,10}$ After washing, both products which have well dispersibility in water were obtained.

\section{Scheme 1}

Initially, the adsorption of DNA onto Im-SPIOs was investigated. The experimental protocols were performed according to the previous work. ${ }^{7}$ To the solutions of the plasmid DNA in Tris- $\mathrm{HCl}$ buffer $(\mathrm{pH}=8.0)$, the dispersion of Im-SPIOs was added. Then, Im-SPIOs were collected with a magnet, and the supernatants were transferred to new tubes. After centrifugation, the samples were applied on $0.8 \%$ agarose gel. Figure 1 shows the picture of the gel stained by ethidium bromide under UV irradiation after the electrophoresis. By increasing the amount of Im-SPIOs, the concentration of the plasmid DNA was obviously reduced. This result indicates that Im-SPIOs can capture DNA (Figure 1, lanes 4, 5, and $6)$.

\section{Figure 1}

To examine the influence of admixtures on the capturing ability of Im-SPIOs with DNA, the adsorption experiments were carried out in the presence of albumin. In the presence of $25 \mathrm{mg} / \mathrm{mL}$ of albumin, the same procedures as above were executed. Remarkably, it was found that Im-SPIOs can capture DNA with similar degree (Figure 1, lanes 7, 8, and 9). These data suggest that the selective adsorption to DNA can be realized with Im-SPIOs. Furthermore, the adsorption experiments were also 
performed in FBS (Figure 2). Although the smearing and shifting of the bands were observed even from the control lanes because of non-specific adsorption of miscellaneous to DNA, it was revealed that the plasmid DNA should be adsorbed onto Im-SPIOs. These data summarized that Im-SPIOs can selectively capture DNA even in the presence of other biomolecules.

Figure 2

The release of DNA via anion exchange was examined with Im-SPIOs. Similarly as the adsorption experiments, the plasmid DNA was mixed with the modified nanoparticles. After washing, $0.5 \mathrm{M}$ KTFSA was added for anion exchange from $\mathrm{Cl}^{-}$to TFSA${ }^{-}$. The supernatant was applied on the gel after centrifugation, and the picture was taken under UV irradiation (Figure 3). As a control without anion exchange, the same procedure was performed with $0.5 \mathrm{M} \mathrm{KCl}$. The plasmid DNA was hardly recovered from the supernatant with the $\mathrm{KCl}$ treatment (Figure 3, lanes 6 and 7). In contrast, the band was observed from the sample with the KTFSA treatment. These data clearly indicate that catch and release of DNA can be controlled with Im-SPIOs by altering the counter anion. It should be mentioned that the heating or drastic $\mathrm{pH}$ changes are not necessary all through the operations.

Figure 3

Phosphate species have strong affinity to the surface of iron oxide nanoparticles. ${ }^{11}$ To improve the release of DNA by suppressing direct adsorption of the phosphate backbone to the surface of iron oxide, the silica layer was introduced. The same procedures for capturing the plasmid DNA were executed with Im-silica-SPIOs, and the amount of DNA in the supernatants was evaluated by gel electrophoresis after anion exchange (Figure 4). Comparing to the sample with Im-SPIOs, the larger amount of DNA was obtained from the sample with Im-silica-SPIOs. These data clearly indicate that the final recovering rate of DNA was greatly improved by the introduction of the silica layer. Moreover, the smearing or 
side bands were hardly observed from the sample even without ethanol precipitation (Figure 4, lanes 5 and 7). Damages on DNA samples could be efficiently suppressed during the operations.

Figure 4

\section{Conclusion}

We describe here the simple protocol for DNA extraction based on the anion exchange of ILs. All operations can proceed at room temperature without large $\mathrm{pH}$ changes and reactive materials. Furthermore, DNA can be selectively captured even in the presence of miscellaneous biological molecules. Our concept could be applicable for developing a simple and efficient purification system for nucleic acids. 


\section{References}

1. M. Uhlen, Magnetic separation of DNA, Nature 340, 733-734 (1989).

2. H. Minehara, A. Narita, K. Naka, K. Tanaka, M. Chujo, M. Nagao and Y. Chujo, Tumor cell-specific prodrugs using arsonic acid-presenting iron oxide nanoparticles with high sensitivity, Bioorg. Med. Chem. 20, 4675-4679 (2012).

3. H. Minehara, K. Naka, K. Tanaka, A. Narita and Y. Chujo, arsonic acid-presenting superparamagnetic iron oxide for $\mathrm{pH}$-responsive aggregation under slight acidic conditions, Bioorg. Med. Chem. 19, 2282-2286 (2011).

4. N. Hirata, K. Tanabe, A. Narita, K. Tanaka, K. Naka, Y. Chujo and S. Nishimoto, Preparation and fuorescence properties of fluorophore-labeled avidin-biotin system immobilized on $\mathrm{Fe}_{3} \mathrm{O}_{4}$ nanoparticles through functional indolequinone linker, Bioorg. Med. Chem. 17, 3775-3781 (2009).

5. H. Itoh, K. Naka, Y. Chujo, Synthesis of gold nanoparticles modified with ionic liquid based on the imidazolium cation, J. Am. Chem. Soc. 126, 3026-3027 (2004).

6. K. Naka, H. Tanaka, Y. Chujo, pH responsive aggregation of imidazolium cations-modified gold nanoparticles with poly(acrylic acid) in aqueous solution, Polym. J. 39, 1122-1127 (2007).

7. K. Naka, A. Narita, H. Tanaka, Y. Chujo, M. Morita, T. Inubushi, I. Nishimura, J. Hiruta, H.

Shibayama, M. Koga, S. Ishibashi, J. Seki, S. Kizaka-Kondoh and M. Hiraoka, Biomedical applications of imidazolium cation-modified iron oxide nanoparticles, Polym. Adv. Technol. 19, 1241-1249 (2008).

8. E. Miyoshi, K. Naka, K. Tanaka, A. Narita and Y. Chujo, Preparation of clusters having various interparticle distances based on imidazolium-modified gold nanoparticles via anion exchange, Colloids Surf., A 390, 126-133 (2011). 
9. K. Tanaka, A. Narita, N. Kitamura, W. Uchiyama, M. Morita, T. Inubushi and Y. Chujo, Preparation for highly-sensitive MRI contrast agents using core/shell type nanoparticles consisted of multiple SPIO cores with thin silica coating, Langmuir 26, 11759-11762 (2010).

10. A. Narita, K. Naka and Y. Chujo, Facile control of silica shell layer thickness on hydrophilic iron oxide nanoparticles via reverse micelle method, Colloids Surf., A 336, 46-56 (2009).

11. K. Tanaka, N. Kitamura, M. Morita, T. Inubushi, Y. Chujo, Assembly system of direct modified superparamagnetic iron oxide nanoparticles for target-specific MRI contrast agents, Bioorg. Med. Chem. Lett. 18, 5463-5465 (2008). 


\section{Table and Figures}

Scheme 1. Outlines of the DNA catch and release by the imidazolium-presenting SPIOs used in this study

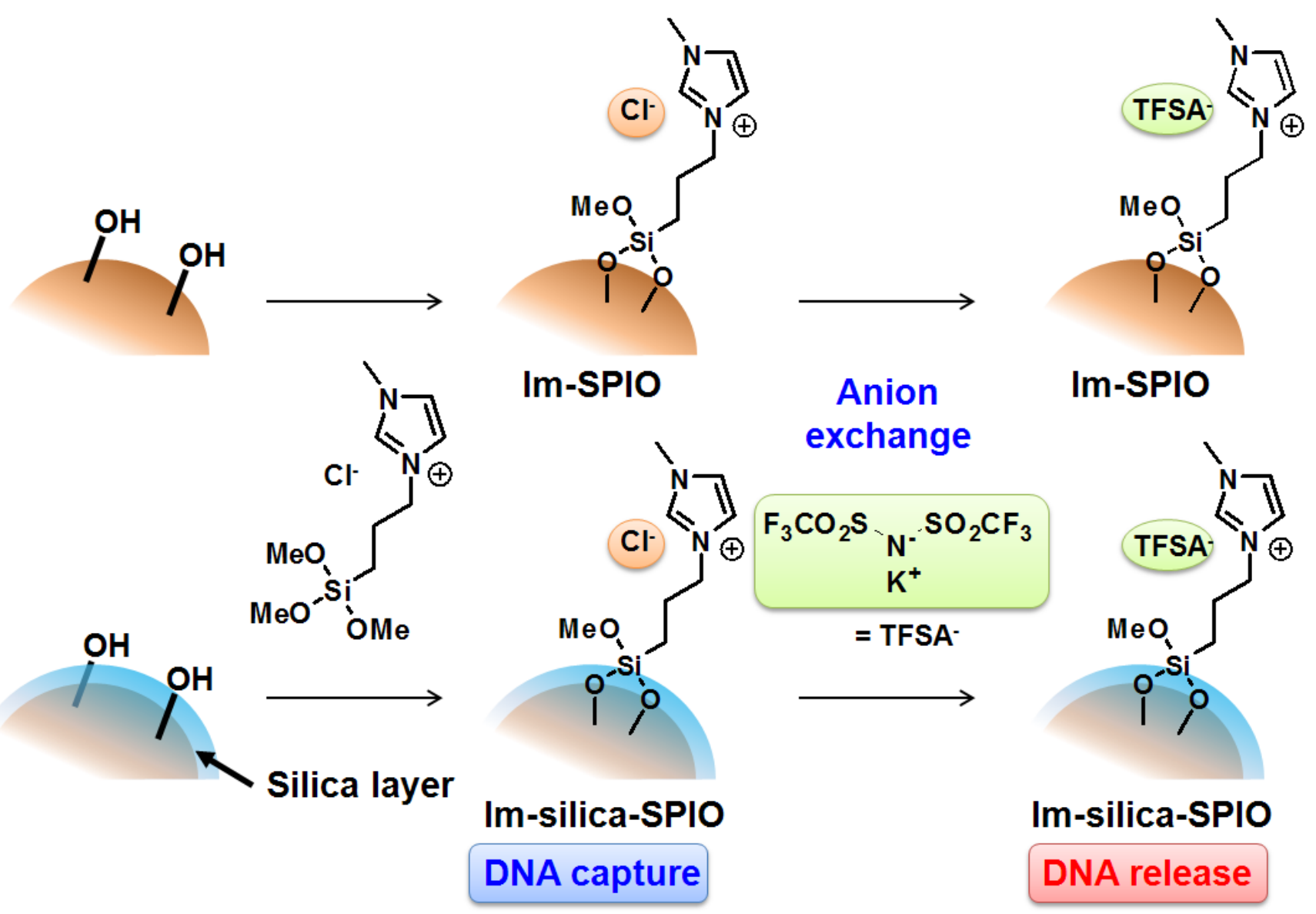




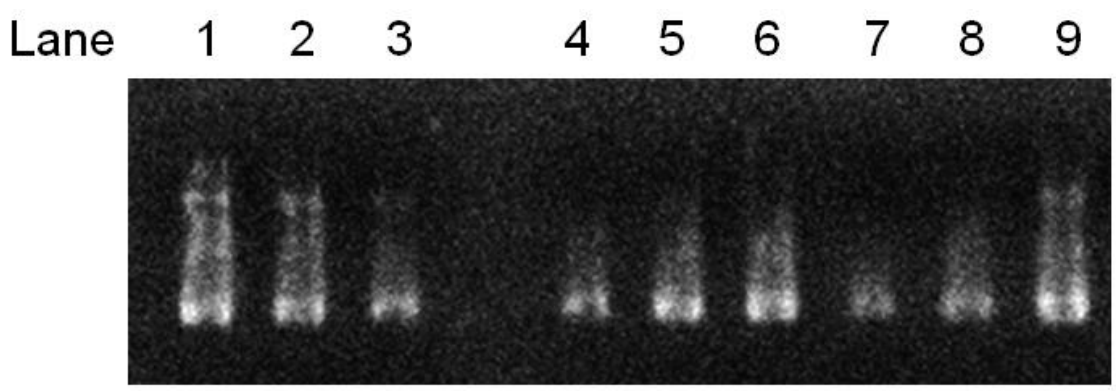

Figure 1. The adsorption of the plasmid DNA onto the Im-SPIOs. Lane 1, $2.5 \mu \mathrm{g}$ of DNA; lane $2,1 \mu \mathrm{g}$ of DNA; lane 3, $0.5 \mu \mathrm{g}$ of DNA; lane 4, the supernatant containing $2.5 \mu \mathrm{g}$ of DNA and $75 \mu \mathrm{g}$ of ImSPIOs; lane 5, the supernatant containing $2.5 \mu \mathrm{g}$ of DNA and $50 \mu \mathrm{g}$ of Im-SPIOs; lane 6, the supernatant containing $2.5 \mu \mathrm{g}$ of DNA and $25 \mu \mathrm{g}$ of Im-SPIOs; lane 7, the supernatant containing $2.5 \mu \mathrm{g}$ of DNA and $75 \mu \mathrm{g}$ of Im-SPIOs in the presence of $25 \mathrm{mg} / \mathrm{mL}$ of albumin; lane 8, the supernatant containing $2.5 \mu \mathrm{g}$ of DNA and $50 \mu \mathrm{g}$ of Im-SPIOs in the presence of $25 \mathrm{mg} / \mathrm{mL}$ of albumin; lane 9 , the supernatant containing $2.5 \mu \mathrm{g}$ of DNA and $25 \mu \mathrm{g}$ of Im-SPIOs in the presence of $25 \mathrm{mg} / \mathrm{mL}$ of albumin. 


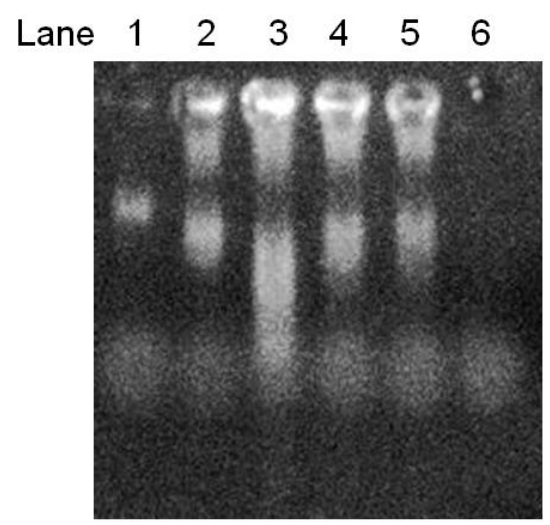

Figure 2. The adsorption of the plasmid DNA onto the Im-SPIOs in the presence of FBS $(\times 1 / 2)$. Lane 1 , $0.5 \mu \mathrm{g}$ of DNA; lane 2, $1 \mu \mathrm{g}$ of DNA; lane 3, $2.5 \mu \mathrm{g}$ of DNA; lane 4, the supernatant containing $2.5 \mu \mathrm{g}$ of DNA and $25 \mu \mathrm{g}$ of Im-SPIOs; lane 5, the supernatant containing $2.5 \mu \mathrm{g}$ of DNA and $50 \mu \mathrm{g}$ of ImSPIOs; lane 6 , the supernatant containing $2.5 \mu \mathrm{g}$ of DNA and $75 \mu \mathrm{g}$ of Im-SPIOs. 

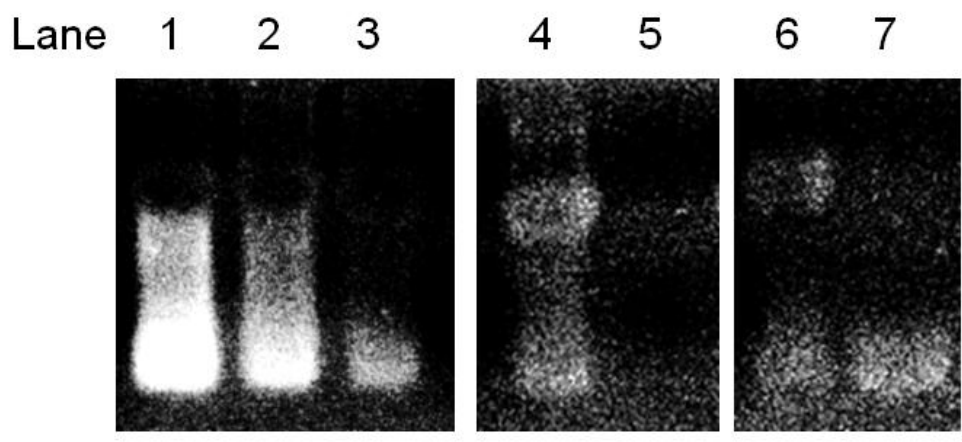

Figure 3. The release of the plasmid DNA from the Im-SPIOs via anion exchange in the presence of FBS $(\times 1 / 2)$. Lane 1, $2.5 \mu \mathrm{g}$ of DNA; lane 2, $1 \mu \mathrm{g}$ of DNA; lane 3, $0.5 \mu \mathrm{g}$ of DNA; lane 4, the supernatant containing $2.5 \mu \mathrm{g}$ of DNA and $50 \mu \mathrm{g}$ of Im-SPIOs; lane 5, the supernatant after adding 0.5 $\mathrm{M} \mathrm{KCl}$ to the DNA-adsorbed Im-SPIOs; lane 6, the supernatant containing $2.5 \mu \mathrm{g}$ of DNA and $50 \mu \mathrm{g}$ of Im-SPIOs; lane 7, the supernatant after adding 0.5 M KTFSA to the DNA-adsorbed Im-SPIOs. 


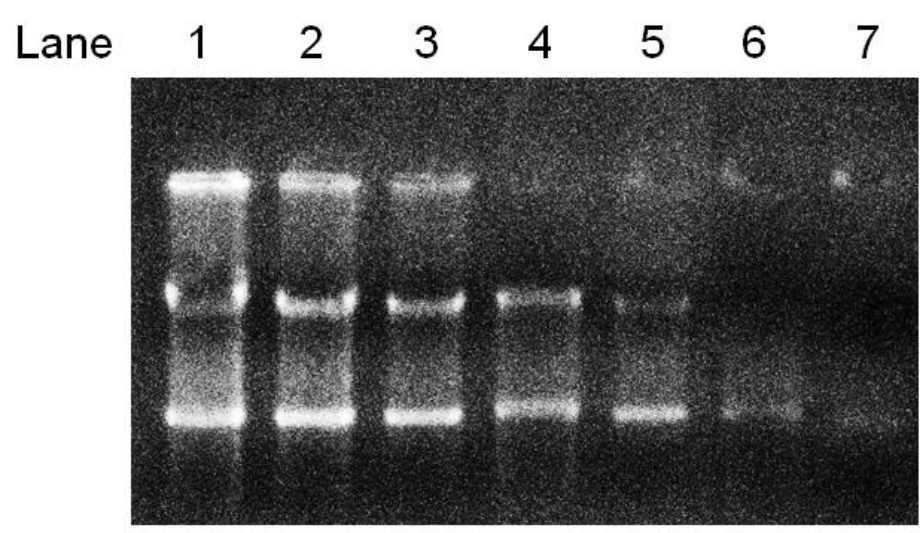

Figure 4. The recovering of the plasmid DNA with the imidazolium-presenting SPIOs via anion exchange in the presence of FBS ( $\times 1 / 2)$. Lane 1, $2.5 \mu \mathrm{g}$ of DNA; lane 2, $1 \mu \mathrm{g}$ of DNA; lane 3, $0.5 \mu \mathrm{g}$ of DNA; lane 4, the supernatant after adding 0.5 M KTFSA to the DNA-adsorbed Im-silica-SPIOs; lane 5, the sample of lane 4 after ethanol precipitation; lane 6, the supernatant after adding $0.5 \mathrm{M}$ KTFSA to the DNA-adsorbed Im-SPIOs; lane 7, the sample of lane 6 after ethanol precipitation. 